RFLP Report

\title{
TWO DINUCLEOTIDE REPEAT POLYMORPHISMS AT THE D8S1218 AND D8S1219 LOCI
}

\author{
Lin Ye, ${ }^{1}$ Jun NAKura, ${ }^{1, *}$ Noriaki Mitsuda, ${ }^{1}$ \\ Asako TAKaHASHI-FuJII, ${ }^{2}$ Yoshizumi IsHINo, ${ }^{2}$ \\ Ikunoshin KATO, ${ }^{2}$ Tetsuro MIKI, ${ }^{1}$ \\ and Toshio OGIHARA ${ }^{1}$ \\ ${ }^{1}$ Department of Geriatric Medicine, Osaka University Medical School, \\ 2-2 Yamadaoka, Suita, Osaka 565, Japan \\ ${ }^{2}$ Biotechnology Research Laboratories, Takara Shuzo Co., Ltd., \\ 3-4-1 Seta, Ohtsu, Shiga 520-21, Japan
}

Summary Two polymorphic dinucleotide (CA) repeat clones were isolated from a CEPH mega-YAC clone (844E2), and were localized to chromosome 8 using a panel of 13 mouse/human somatic cell hybrids.

Key Words microsatellite, YAC, cosmid, chromosome 8

A YAC clone (844E2) was subcloned into cosmids which were prepared without previous separation of cloned DNA from host DNA. The cosmids were hybridized with ${ }^{32} \mathrm{P}$-labelled total human DNA in order to select the cosmids with human inserts. The selected cosmids were screened on the basis of hybridization to a ${ }^{32}$ P-labelled poly $(\mathrm{dA}-\mathrm{dC}) \cdot$ poly $(\mathrm{dG}-\mathrm{dT})$ probe (Pharmacia) (Nagano et al., 1993). The positive cosmids were digested completely with HaeIII. HaeIIIfragments were subcloned into the SmaI site of pUC18 and hybridized with a ${ }^{32} \mathrm{P}-$ labelled poly $(\mathrm{dA}-\mathrm{dC}) \cdot \operatorname{poly}(\mathrm{dG}-\mathrm{dT})$ probe again. Each positive subclone was partially sequenced and the sequences flanking a $(\mathrm{CA})_{n}$ repeat were used to design PCR primers. Thus two dinucleotide repeat polymorphisms, M3073 and M3136 (Genbank accession number: G00-389-817), were isolated from the YAC clone (844E2).

$$
\begin{aligned}
& \text { Primers for } P C R \\
& \mathrm{M} 3073-\mathrm{F}=5^{\prime} \text { GGCTGGTCTCTGATTCA } 3^{\prime} \\
& \mathrm{M} 3073-\mathrm{R}=5^{\prime} \text { CTGTTATGGCAATTATCT } 3^{\prime} \\
& \mathrm{M} 3136-\mathrm{F}=5^{\prime} \text { GAATAGTTATTTAGCTTGA } 3^{\prime} \\
& \mathrm{M} 3136-\mathrm{R}=5^{\prime} \text { GAGGATATTAAGATGCGC } 3^{\prime}
\end{aligned}
$$

Received January 24, 1996; Revised version accepted March 28, 1996.

* To whom correspondence should be addressed. 


\section{Polymorphism / frequency}

M3073 (D8S1218): Five alleles were detected in 96 chromosomes of unrelated Japanese individuals. Observed heterozygosity $=0.69$.

$\begin{array}{lll}\text { Allele } & \text { Size (bp) } & \text { Frequency } \\ \text { A1 } & 109 & 0.01 \\ \text { A2 } & 111 & 0.41 \\ \text { A3 } & 117 & 0.28 \\ \text { A4 } & 119 & 0.29 \\ \text { A5 } & 121 & 0.01\end{array}$

M3136 (D8S1219): Seven alleles were detected in 92 chromosomes of unrelated Japanese individuals. Observed heterozygosity $=0.48$.

$\begin{array}{lll}\text { Allele } & \text { Size }(b p) & \text { Frequency } \\ \text { Al } & 104 & 0.68 \\ \text { A2 } & 106 & 0.01 \\ \text { A3 } & 110 & 0.13 \\ \text { A4 } & 112 & 0.01 \\ \text { A5 } & 116 & 0.14 \\ \text { A6 } & 118 & 0.01 \\ \text { A7 } & 122 & 0.01\end{array}$

Chromosomal localization. Both ends of the YAC clone (844E2) and the two polymorphic dinucleotide (CA) repeat clones (D8S1218 and D8S1219) were localized to chromosome 8 using a panel of 13 mouse/human somatic cell hybrids (Semba et al., 1985).

Mendelian inheritance. Mendelian inheritance was observed.

Amplification conditions. PCR reaction was carried out in a total volume of $10 \mu 1$ containing $20 \mathrm{ng}$ of genomic DNA, 2 pmol of rhodamine-labelled primers, $200 \mu \mathrm{M}$ dNTP, $1 \%$ formamide, $2 \mathrm{mM} \mathrm{MgCl}_{2}, 50 \mathrm{mM} \mathrm{KCl}, 0.001 \%$ gelatin, $10 \mathrm{~mm}$ Tris- $\mathrm{HCl}$ at $\mathrm{pH} 8.4$ and $0.25 \mathrm{U}$ Taq polymerase, using a Perkin Elmer Cetus Thermal Cycler for 30 cycles as follows: $94^{\circ} \mathrm{C}$ for $30 \mathrm{sec}$, annealing temperature $\left(45^{\circ} \mathrm{C}\right.$ for $\mathrm{M} 3073$ and $47^{\circ} \mathrm{C}$ for M3136) for $30 \mathrm{sec}$, and $72^{\circ} \mathrm{C}$ for $30 \mathrm{sec}$ for each cycle. The amplified product was fractionated on a $6 \%$ polyacrylamide gel and images were obtained by scanning the gels with a fluorescent image analyzer FMBIO (Ishino et al., 1992; Nakura et al., 1995). The size of the alleles was determined by comparison to M13mp18 DNA sequencing ladders.

Acknowledgments We are grateful to Dr. Fumihiko Matsuda for his technical advice. We also thank Dr. Denis Le Paslier for his support to identify the YAC clone. This work was partly supported by a Grant-in-Aid for Creative Basic Research (Human Genome Program) from the 
Ministry of Education, Science and Culture of Japan, and a grant of the Research Project on Health and Aging.

\section{REFERENCES}

Ishino Y, Mineno J, Inoue T, Fujimiya H, Yamamoto K, Tamura T, Homma M, Tanaka K, Kato I (1992): Practical application in molecular biology of sensitive fluorescence detection by a laser-excited fluorescence image analyzer. Biotechniques 13: 936-943

Nagano K, Nakura J, Kihara K, Ye L, Kamino K, Mitsuda M, Ohta T, Jinno Y, Niikawa N, Miki T, Ogihara T (1993): Isolation and mapping of microsatellites from a library microdissected from the Werner's syndrome region, 8p11.2-p22. Jpn J Human Genet 38: 391-397

Nakura J, Ye L, Mitsuda N, Takahashi-Fujii A, Ishino Y, Miki T, Ogihara T (1995): Dinucleotide repeat polymorphism at the D8S1053. Jpn J Human Genet 39: 445-446

Semba K, Yamanashi Y, Nishizawa M, Sukegawa J, Yoshida M, Sasaki M, Yamamoto T, Toyoshima K (1985): Location of the c-yes gene on the human chromosome and its expression in various tissues. Science 227: 1038-1040 